\title{
THE COLOURING OF SIXTEENTH-CENTURY HERBALS
}

\author{
By Dr. Agnes Arber
}

$\mathrm{I}^{\mathrm{N}}$ many copies of sixteenth-century herbals the woodcuts are coloured, but we have little direct information as to when, and under what conditions, the painting was done. For this reason it may be worth while to direct attention to certain points which seem hitherto to have escaped notice in connexion with the colouring of one of the most beautiful of these works- "De historia stirpium" by Leonhart Fuchs, published by Isingrin at Basle in 1542. In the description of maize (Cap. ccexviii) the following words occur : "Haec [pictura] in una vagina quatuor tibi granorum colores monstrat, cum tamen quaevis unius duntaxat coloris grana, nempe aut lutea, aut purpurea, aut rufa, aut subcandida omnia habeat. Quod nos, ne aliquem pictura deciperet, monendum esse duximus." This careful explanation that the grains are indicated in four colours-yellow, purple, reddish, and whitish-in one cob, though these variants would not, in fact, be found together, shows clearly that coloured copies must have formed an integral part of the edition, for Fuchs's words would be meaningless if the whole edition had been issued uncoloured.

In painted copies in the libraries of Winchester Cathedral, and of the Linnean Society*, the four colours which Fuchs mentions in the text are represented in horizontal zones in the one maize cob in which the grains can be seen. In similar coloured copies in the University Library, Cambridge (Sel. 2. 81), and in the Library of Corpus Christi College, Cambridge, there is also an attempt at zoning, though the pigments are less well defined. I find, on comparing the general colouring of the two latter copies, that they show certain other points of agreement. For example, both in "Endivien" (endive) and in "Wegwart" (chicory) several flower-heads are shown in blue, while one is indicated in white. This is consistent with Fuchs's descriptions, in which it is noted that both these species are sometimes white-flowered (Cap. colxii).

A more remarkable case is that of the woodcut called "Lamium" (Cap. clxxvi). It is a composite figure consisting of three shoots growing from a common base, and according to Fuchs's statement, these shoots are intended to represent the yellow archangel, a purple dead-nettle, and the white dead-nettle. In the two copies under comparison,

- For information on this point I am indebted to the librarians of Winchester Cathedral Library, and of the Linnean Society. the flowers are distinguished in hue in accordance with the description, and the intention of Fuchs's tripartite picture is thus fully carried out. Moreover, the arrangement is identical in the two copies, the three shoots having yellow, pinkishmauve, and white flowers, in the order from left to right. In the picture of "Prunus sativa", again, in both copies the tree is so painted as to have yellow plums to the left, blue in the middle, and pinkish-red to the right. Furthermore, in the picture of "Rosa", in both copies the left hand shoot bears white flowers, while those to the right are red.

These examples of accordance in individual details between the colouring and the text, and between different coloured copies, make it probable that the author to some extent controlled the painting. We know that uncoloured copies were also issued, for many of them have come down to us in the untouched state, and some are said to have been painted afterwards by their owners. It is scarcely likely, however, that an amateur, doing the work for his own pleasure, would have taken the trouble to follow out the peculiarities and idiosyncrasies of the text so accurately as has been done in the examples here cited. In the Cambridge University Library copy it is noticeable that the painting is better in its general scheme than it is in the detail, which has a certain rough, mechanical look, which might result from the colourist having to deal rapidly with a number of copies ; this is not the kind of imperfection that one would look for in the work of an owner-artist.

Curiously enough, we happen to know something of a much later occasion on which the woodcuts from "De historia stirpium" were coloured before they were sold. In 1774, more than two hundred years after Fuchs's death, a certain Salomon Schinz, who had somehow obtained the blocks cut for Fuchs's herbal, used them to illustrate a book published at Zurich under the title of "Anleitung zu der Pflanzenkenntniss". He had the woodcuts coloured by the children of an orphanage-an economical method of producing éditions de luxe, which was apparently not unusual in the eighteenth century. It is pleasant to find that Schinz gives full credit to the orphans, whom he praises in his preface for the pictures, "Durch Euch, liebe Knaben, in Farben dargestellt".

Turning again to the sixteenth century, we may recall. Dr. Sprague's crucial discovery ${ }^{1}$ that a 
study of the painted copy of Otto Brunfels's herbal of 1530- "Herbarum vivæ eicones"belonging to the Kew Herbarium Library, makes it probable that the original water-colours by Hans Weiditz, who illustrated the herbal, were used as patterns for the colours. This view would imply that the Kew copy was painted before it left the publisher's office.

The pieces of evidence so far considered are based on a study of coloured copies of the two primary German herbals of the Renaissance. In addition, we already possess evidence of a more factual kind, derived from the records of a great printing house-that founded by Christophe Plantin of Antwerp, who published the herbals of the 'triumvirate' of Low Country botanistsDodoens, de l'Écluse, and de l'Obel. M. Bouchery, of the Museum Plantin-Moretus, kindly informed me by letter in 1938 that, in the Plantin Archives, numerous references occur to three women who were employed to colour herbals. These were Lisken Zegers; Myncken, the widow of Hans
Liefrinck; and Lyncken, the widow of Abraham Verhoeven. Any student, to whom the original documents at Antwerp are accessible, might be able to unravel the exact part played by these painters in relation to the authors, and to the other artists who were members of Plantin's staff.

To sum up, we may say that the evidence here considered suggests that the colouring of sixteenthcentury herbals by individual owners was less frequent than has often been supposed; it can indeed have happened but rarely that an amateur was capable of carrying so onerous a task to completion. There seems more probability in the alternative that the colouring was as a rule done officially before the books were sold. If further study shows this view to be of general application, it means that coloured copies deserve more attention than has hitherto been accorded to them, since they may prove to provide an authoritative commentary on the text, and to emphasize the intentions of the author.

${ }^{1}$ Trans. South-East Union Sci. Soc., 43, 36 (1938).

\section{OB ITUARIES}

\section{Prof. Wilhelm Dörpfeld}

$\mathrm{W}$ E regret to record the death of Prof. Wilhelm Dörpfeld on April 26, at the age of eighty-six. Born and educated at Barmen near Düsseldorf, Wilhelm Dörpfeld studied architecture in Berlin, and in 1877 was called from the Prussian Board of Works to be architectural assistant to Dr. Adler at the excavations of the German Archaeological Institute at Olympia, and in 1878 he became technical director. From Olympia he went to help Schliemann at Hissarlik, and collaborated in his publications "Troy" (1884) and "Tiryns" (1886). In 1883 he had married Adler's daughter, and in 1886 he became architectural adviser to the German School in Athens; and in 1887 its 'first secretary', that is, director. After Schliemann's death in December 1890 he continued his work at Hissarlik, revealing the significance of the 'Sixth City' in his "Troja 1893", and reviewing the whole series of discoveries in "Troja und Ilion" (1902).

Meanwhile at Athens he devoted himself to topographical and architectural problems, propounding some original views about the early water supply, and the ground plan of the Erechtheum and Propylaea. He gave remarkable open-air lectures on the sites, and conducted annually a large party of students through Greece, and later also through the islands and to Crete. In 1896, he published, with the philological aid of Reisch, his revolutionary book "Das Griechische Theater", contending that, in the earlier drama, actors spoke not from a raised stage but on the same level as the chorus. After much controversy, this is now generally accepted, though there may be doubt as to the date when the raised platform came into use and assumed the name of the original back-scene (skenê).
On the discoveries of prehistoric civilization in Crete, from 1900 onwards, Dörpfeld supported vigorously, but with insufficient local study, the conjecture of Koehler, his predecessor at Athens, that an Aryan culture could be distinguished from a pre-Aryan in the Ægean.

From 1905, Dörpfeld spent much time in excavation in Leucas, which he claimed as the Homeric Ithaca ; but neither his rendering of the topography, nor his theory of a general southward shift of island names, nor his archæological finds, have availed to establish the views embodied in "Alt Ithaka" (1927), nor his defence, in "Homer's Odyssee" (1924), of the notion of Helbig that the 'Mycenaean' civilization was of Phoenician origin, and of Conze that the primitive Hellenes practised 'geometrical' art.

After his retirement from the Institute in 1912, Dörpfeld lived in Germany, and held an honorary chair of archæology at Jena; but he frequently returned to Greece, and even excavated at the reputed 'Pylos' of the "Odyssey", and in the prehistoric subsoil of Olympia. Latterly he spent much time in his beloved Leucas, and here he is buried in a tomb prepared by himself overlooking the sea of Odysseus.

Always robust, Dörpfeld was a distinguished figure at the International Archæological Congress so recently as August 1939. He will be remembered with affection for his remarkable powers of exposition, his gift of inspiring friendship and enthusiasm for his views, his tenacious defence of ingenious theories; but above all for his simple open nature and his delight in the scenes and studies to which he devoted' his life.
JOHN L. MYres. 